\title{
Implementasi Kebijakan Pariwisata Halal Di NTB (Studi Implementasi Kebijakan Peraturan Daerah Provinsi NTB No.2 Tahun 2016 Tentang Pariwisata Halal) \\ Rahmad Hidayat ${ }^{1}$, M. Awaluddin ${ }^{2}$, Candra ${ }^{3}$ \\ ${ }^{1}$ Prodi Administrasi Publik, Universitas Muhammadiyah Mataram, email: rahmad_dayat22@yahoo.com \\ ${ }^{2}$ Prodi Administrasi Publik, Universitas Muhammadiyah Mataram, Email: awaldompu@gmail.com \\ ${ }^{3}$ Prodi Administrasi Publik, Universitas Muhammadiyah Mataram, Indonesia
}

\section{INFO ARTIKEL}

\section{Riwayat Artikel:}

Diterima: 08-08-2018

Disetujui: $10-08-2018$

\section{Kata Kunci:}

1. Implementasi

2. Kebijakan

3. Pariwisata

4. Halal

5. NTB
Keyword:
1. Implementation
2. Policy
3. Tourism
4. Halal
5. NTB

\section{ABSTRAK}

Abstrak: Indonesia memang salah satu Negara yang menjadi destinasi wisata bagi wisatawan luar negeri. Spot wisata yang relatif banyak membuat Indonesia menjadi tujuan wisata yang banyak diburu oleh wisatawan mancanegara. NTB memiliki keunggulan dari segi budaya, masyarakatnya $95 \%$ muslim, religius, daerah seribu mesjid. Hal ini menjadi modal dasar NTB optimis mampu menjadi wisata halal dunia.

Berdasarkan hasil penelitian dapat disimpulkan yaitu: Proses Implementasi Kebijakan Pariwisata Halal di NTB berdasarkan Peraturan Daerah Provinsi NTB No.2 tahun 2016 Tentang Pariwisata Halal oleh Dinas Pariwisata Provinsi NTB sudah berjalan dengan baik namun belum maksimal. Faktor komunikasi, sumberdaya, disposisi dan struktur birokrasi sudah dijalankan untuk mensukseskan kebijakan ini. Sedangkan faktor penghambat dalam mempengaruhi proses Implementasi Kebijakan Pariwisata Halal di NTB oleh Dinas Pariwisata Provinsi NTB yaitu masing kurangnya objek wisata halal dan masing kurangnya kesadaran pelaku usaha untuk mewujudkan konsep pariwisata halal.

\section{Abstract}

Indonesia is indeed one of the countries that has become a tourist destination for foreign tourists. Relatively large tourist spots make Indonesia a tourist destination that is mostly hunted by foreign tourists. NTB has cultural advantages, its people are 95\% Muslim, religious, a thousand mosques. This is the basic capital of NTB, optimistic that it can become a world halal tourism. Based on the results of the study, it can be concluded that: The process of implementing Halal Tourism Policy in NTB based on NTB Provincial Regulation No. 2 of 2016 concerning Halal Tourism by the NTB Province Tourism Office has been going well but not yet maximally. Communication, resources, disposition and bureaucratic structure factors have been carried out to make this policy a success. While the inhibiting factors in influencing the process of implementing Halal Tourism Policy in NTB by the NTB Province Tourism Office are each lack of halal tourism objects and each lack of awareness of business people to realize the concept of halal tourism. 


\section{Latar Belakang}

Indonesia memang salah satu Negara yang menjadi destinasi wisata bagi wisatawan luar negeri. Spot wisata yang relatif banyak membuat Indonesia menjadi tujuan wisata yang banyak diburu oleh wisatawan mancanegara. Kebijakan dari pemerintah tentang pengembangan wisata di Indonesia memang harus menjadi prioritas utama, karena wisata merupakan salah satu penyumbang terbesar APBD.

Salah satu kebijakan yang dikeluarkan pemerintah saat ini adalah wisata halal yang menjadi perbincangan bagi khalayak umum. Indonesia sebagai salah satu Negara dengan mayoritas umat muslim terbesar di dunia memang sangat cocok untuk kebijakan wisata halal. Tidak hanya itu, NTB yang dijuluki "Pulau Seribu Mesjid" menjadi point penting tentang wisata halal sendiri.

Dengan adanya wisata halal yang dikeluarkan oleh pemerintah tentunya wisatawan muslim yang ingin berwisata ke pulau Lombok tentunya akan lebih nyaman karena banyak wisatawan asing yang inin menunjuni destinasi wisata denan penunjan yan tidak terlalu menumbar aurat wisatawannya. Jadi denan adanya kebijakan wisata halal ini diharapkan tourist yan inin menunjuni destinasi wisata di Indonesia khususnya pulau Lombok akan lebih nyaman dan berkemban. Selain itu, kebijakan ini jua bisa menjadi peluan bai daerah NTB memiliki keunggulan dari segi budaya, masyarakatnya 95\% muslim, reliius, daerah seribu mesjid jadi bukan sesuatu yan dibuat-buat. Hal ini menjadi modal dasar NTB optimis mampu menjadi wisata halal dunia.

Dilihat dari target kunjungan wisatawan yang ditetapkan oleh Pemerintah Provinsi NTB pada tahun 2017 adalah sejumlah 3,5 juta wisatawan dimana 30 persen ditargetkan merupakan wisatawan muslim, maka target tersebut dianggap cukup realistis mengingat pada tahun 2016 jumlah kunjungan wisatwan muslim yang berkunjung ke NTB mencapai 60 ribu wisatawan. Jumlah tersebut dianggap realistis karena pada tahun 2017 berbagai event untuk menarik minat wisatawan muslim akan diadakan di Pulau Lombok, salah satunya adalah Pesona Khazanah Ramadhan yang akan dilaksanakan selama satu bulan penuh pada bulan Ramadhan.

Sesuai dengan Perda Provinsi NTB Nomor 2 tahun 2016, pariwisata halal didefinisikan sebagai kegiatan kunjungan wisata dengan destinasi dan industri pariwisata yang menyiapkan fasilitas produk, pelayanan, dan pengelolaan pariwisata yang memenuhisyari'ah. Dalam Perda tersebut juga menjelaskan yang dimaksud industri pariwisata halal adalah usahausaha wisata yang menjual jasa dan produk kepariwistaan yang berpatokan pada prinsipprinsip syari'ah sebagaimana yang ditetapkan oleh DSN-MUI. Industri parwisata halal yang dimaksud di atas diantaranya adalah akomodasi, biro perjalanan, restoran dan SPA.

\section{Tinjauan Pustaka}

\section{a. Administrasi Publik}

Definisi Administrasi Publik menurut Chandler dan Plano dalam Pasolong, Harbani (2011:7), mengatakan bahwa Administrasi Publik adalah proses dimana Sumber Daya dan personel Publik diorganisir dan dikoordinasikan untuk memformulasikan, mengimplementasikan, dan mengelola (manage) keputusan-keputusan dalam Kebijakan Publik. Konsep Administrasi Publik di Indonesia pada dasarnya bukanlah konsep yang baru, karena konsep administrasi Publik sudah ada sejak dari dulu, hanya para pakar yang mengganti istilah Administrasi Publik menjadi Administrasi Negara. Begitu pula buku-buku asing misalnya yang berjudul "Public Adminitration" diganti menjadi Administrasi Negara. Jika ada para pakar yang mengatakan bahwa Administrasi Negara perlu direformasi menjadi Administrasi Publik, maka itu dapat dikatakan kesalahan berfikir, karena Administrasi Publik sudah ada sejak dari dulu. (Pasolong, 2012:55).

Chandler \& Plano dalam Pasolong (2012:55), menjelaskan bahwa Administrasi Publik merupakan Seni dan Ilmu yang ditujukan untuk mengatur "Publik Affairs" dan melaksanakan berbagai tugas yang ditentukan. Administrasi Publik sebagai disiplin ilmu bertujuan untuk memecahkan Masalah Publik melalui perbaikan-perbaikan terutama dibidang organisasi, sumberdaya manusia dan keuangan. Menurut Nicholas Hendry dalam Pasolong (2012:56) mendefinisikan "Administrasi Publik adalah suatu kombinasi yang kompleks antara teori dan praktik, dengan tujuan mempromosikan pemahaman terhadap pemerintah dalam hubungannya dengan masyarakat yang diperintah, dan juga mendorong kebijakan 
publik agar lebih responsif terhadap kebutuhan sosial".

George J. Gordo dalam Inu Kencana, (51:2015) Administrasi Publik dapat dirumuskan sebagai seluruh proses yang baik yang dilakukan organisasi maupun perseorangan yang berkaitan dengan penerapan atau pelaksanaan hukum dan peraturan yang dikeluarkan oleh badan legislatif, eksekutif serta peradilan. Administrasi Publik dimaksudkan untuk lebih memahami hubungan pemerintah dengan publik serta meningkatkan responbilitas kebijakan terhadap berbagai kebutuhan publik, dan juga melembagakan praktik-praktik manajerial agar terbiasa melaksanakan suatu kegiatan dengan efektif, efisien dan rasional.

Beberapa definisi Administrasi Publik yang telah dikemukakan oleh para ahli di atas, dapat dipahami bahwa Administrasi Publik adalah kerjasama yang dilakukan oleh sekelompok orang atau lembaga dalam melaksanakan tugas-tugas pemerintahan dalam memenuhi kebutuhan publik secara efesien dan efektif.

\section{b. Implementasi Kebijakan}

Implementasi kebijakan merupakan suatu proses yang begitu kompleks bahkan bermuatan politis dengan adanya intervensi berbagai kepentingan. Van Meter dan Van Horn dalam Leo Agustino (2014:139) mendefinisikan implementasi kebijakan publik adalah tindakan-tindakan yang dilakukan baik oleh individu-individu atau pejabat-pejabat atau kelompok-kelompok pemerintah atau swasta yang diarahkan pada tercapainya tujuan-tujuan yang telah digariskan dalam keputusan kebijaksanaan.Unsur terpenting dalam implementasi kebijakan adalah adanya tujuan atau sasaran kebijakan, adanya aktivitas atau kegiatan pencapaian tujuan dan adanya hasil kegiatan. Sedangkan untuk mengetahui sejauh mana keberhasilan suatu implementasi kebijakan bisa dilihat melalui proses dan pencapaian tujuan hasil akhir.

Guna mencapai tujuan kebijakan, pemerintah harus melakukan aksi atau tindakan berupa penghimpunan sumber daya dan pengolaan sumber daya tersebut. Hasil dari aksi pertama dapat disebut input kebijakan aksi yang kedua secara terbatas disebut sebagai proses (implementasi) kebijakan. Sedangkan konsekuensi kebijakan memiliki dua jenis pemahaman yaitu hasil (output) dan dampak. Salah satu tahap penting dalam siklus kebijakan publik adalah implementasi kebijakan.

\section{Metode Penelitian}

Jenis penelitian yang dipergunakan adalah penelitian deskriptif dengan pendekatan kualitatif. Menurut Denzin dan Lincoln seperti dikutip Moleong (2007:5) menyebutkan bahwa penelitian kualitatif adalah penelitian yang menggunakan latar alamiah yang bermaksud untuk menafsirkan fenomena yang terjadi dan dilakukan dengan jalan melibatkan berbagai metode yang ada.

Jenis penelitian deskriptif bertujuan untuk memberikan gambaran secara tepat sifat-sifat suatu individu, keadaan, gejala atau kelompok tertentu, atau untuk menentukan frekuensi atau penyebaran suatu gejala lain dalam masyarakat (Muslimin, 2002:15). Dengan demikian, dalam penelitian ini peneliti memaparkan, menggambarkan atau mendeskripsikan karakteristik dari obyek yang akan diteliti agar didapatkan gambaran yang jelas, sistematik, dan faktual dari obyek penelitian agar lebih mudah untuk dipahami dan disimpulkan yaitu terkait pengelolaan parkir di lokasi penelitian. Adapun lokasi penelitian ini untuk penelitian ini dilakukan di Dinas Pariwisata Provinsi NTB. Dalam hal pengolahan dan analisis data kualitatif, menurut Miles dan Huberman (1992) menyatakan bahwa analisis data kualitatif menggunakan kata-kata yang selalu disusun dalam sebuah teks yang diperluas atau yang dideskripsikan. Pada saat memberikan makna pada data yang dikumpulkan, data tersebut bersifat kualitatif, maka dilakukan analisis data. Pertama, dikumpulkan hingga penelitian itu berakhir secara simultan dan terus menerus. Selanjutnya, interpretasi dan penafsiran data dilakukan dengan mengacu pada rujukan teoritis yang berhubungan atau yang berkaitan dengan permasalahan penelitian. Lebih lanjut menurut Miles dan Huberman mendefenisikan bahwa analisis terdiri dari tiga alur kegiatan yang terjadi/terkait secara bersamaan dan interaktif yaitu : reduksi data (reduction data), penyajian data (diplay data) dan penarikan kesimpulan/verifikasi (concluncing drawing) (Miles dan Huberman, 1992:16). Dalam penelitian ini, teknik 
pengumpulan data yang digunakan dibedakan menjadi tiga, yaitu :
1. Wawancara
2. Observasi
3. Dokumentasi

\section{HASIL DAN PEMBAHASAN}

\section{a) Proses Implementasi Kebijakan Pariwisata Halal di NTB berdasarkan Peraturan Daerah Provinsi NTB No.2 tahun 2016 Tentang Pariwsata Halal oleh Dinas Pariwisata Provinsi NTB.}

Pada tahun 2016 pemerintah NTB menerbitkan perda mengenai wisata halal yang merupakan pertama di Indonesia. Dalam perda tersebut diatur layanan bagi restoran, hotel, spa dan penyelenggara wisata lainnya dapat memiliki sertifikasi halal. Restoran di hotel harus memiliki sertifikasi halal secara bertahap. Hotel tempat menginap wajib menyediakan ruangan permanen dan perlengkapan untuk sholat. Layanan spa dipisahkan antara layanan laki-laki dan perempuan.

Dinas pariwisata NTB tahun 2018 menargetkan 4 juta kunjungan turis, meningkat 3,5 juta orang dari tahun sebelumnya. 2 juta orang wisatawan mancanegara yang sebagian besar dari Malaysia dan Timur Tengah. Sedangkan pada tahun 2016 target wisatawan mencapai 3 juta orang. Secara ringkas bisa dilihat dalam tabel dibawah ini.

\begin{tabular}{|l|l|l|l|l|l|}
\hline $\begin{array}{l}\mathbf{N} \\
\mathbf{o}\end{array}$ & $\begin{array}{l}\text { Tahu } \\
\mathbf{n}\end{array}$ & $\begin{array}{l}\text { Jumlah } \\
\text { Wisatawan }\end{array}$ & Nusantara & $\begin{array}{l}\text { Mancanega } \\
\text { ra }\end{array}$ & $\begin{array}{l}\text { Target } \\
\text { Wisatawa } \\
\text { n Muslim }\end{array}$ \\
\hline 1 & $\begin{array}{l}201 \\
5\end{array}$ & $\begin{array}{l}2.210 .52 \\
7\end{array}$ & $\begin{array}{l}1.149 .23 \\
5\end{array}$ & $\begin{array}{l}1.061 .29 \\
2\end{array}$ & - \\
\hline 2 & 201 & 3.094 .43 & 1.690 .10 & 1.404 .32 & $\begin{array}{l}20- \\
8\end{array}$ \\
& 6 & 7 & 9 & 8 & $30 \%$ \\
\hline 3 & 201 & 3.508 .90 & 2.078 .65 & 1.430 .25 & $20-$ \\
& 7 & 3 & 4 & 9 & $30 \%$ \\
\hline 4 & $\begin{array}{l}201 \\
8\end{array}$ & 4 Juta & & & $20-$ \\
& & & & $30 \%$ \\
\hline
\end{tabular}

Anderson sebagaimana dikutip oleh Winarno (2002) menyebutkan bahwa kebijakan publik "purposive course of actions or inactions undertaken by an actors or set of actors in dealing with a problem or matter of concern" (merupakan arah langkah tindakan yang mempunyai maksud yang ditetapkan seseorang atau sejumlah aktor dalam menangani suatu masalah atau persoalan). Dalam hal ini, pemerintah Provinsi NTB membentuk Perda No.2 tahun 2016 Tentang Pariwsata Halal untuk memperkuat sekaligus menjadi landasan pokok dalam aktivitas kepariwisataan yang halal.
Namun demikian, perlu dilihat bagaimana kebijakan tersebut di implementasikan.

Penelitian ini berdasarkan teori implementasi dari Edward III yang menyarankan untuk memperhatikan empat unsur pokok atau variabel agar implementasi kebijakan menjadi efektif, yaitu communication, resources, disposition or attitude dan bureaucratic structures (Nugroho, 2011).

\section{a) Proses Komunikasi Perda}

Hasil penelitian pada Dinas Pariwisata Provinsi NTB, menunjukan bahwa sektor pariwisata halal di NTB udah mulai maju dengan tingkat tamu mancanegara yang semakin tinggi. Menurut H.M. Haris selaku Kepala Seksi Pariwisata Halal Bagian pemasaran menyampaikan kembali dengan mendasarkan pada uraian Kepala Dinas Kebudayaan dan Pariwisata NTB bahwa "Perda NTB No. 2 Tahun 2016 tentang Pariwisata Halal merupakan pelaksanaan dari kekhususan daerah sebagaimana diatur dalam UU No. 23 Tahun 2014 tentang Pemerintahan Daerah". Pada Pasal 236 ayat (3) huruf $b$ memuat ketentuan bahwa materi Peraturan Daerah merupakan penjabaran lebih lanjut ketentuan peraturan perundangundangan yang lebih tinggi.

Lebih lanjut menurut narasumber yang sama, "maka dari itu, Perda NTB No. 2 Tahun 2016 juga lahir berdasarkan ketentuan UU No. 10 Tahun 2009 tentang Kepariwisataan sebagai pedoman umum dan sebagai dasar pembangunan pariwisata halal. Sebagaimana yang dimuat dalam UU No. 10 Tahun Pasal 20 huruf $\mathrm{c}$ menyatakan bahwa wisatawan berhak mendapatkan perlindungan hukum dan keamanan, kemudian Pasal 23 ayat (1) diantaranya mengamanatkan bahwa Pemerintah dan Pemerintah Daerah berkewajiban memberikan perlindungan hukum dan menciptakan iklim yang kondusif untuk perkembangan usaha pariwisata yang meliputi terbukanya kesempatan yang sama dalam berusaha, memfasilitasi, dan memberikan kepastian hukum".

Berdasarkan hasil wawancara itu bahwa ketentuan umum yang ditentukan oleh UU No. 10 Tahun 2009 tersebut, maka dapat dimaknai pula bahwa langkah Pemerintah Provinsi NTB membentuk Perda NTB No. 2 Tahun 2016 merupakan sebuah langkah perlindungan hukum kepada wisatawan dan sebagai pemenuhan kewajiban yang ditentukan oleh UU No. 10 Tahun 2009. Perlindungan tersebut ditunjukan pada dasar pertimbangan yang dimuat dalam 
konsideran Perda NTB No. 2 Tahun 2016 menyatakan bahwa usaha Pariwisata Halal merupakan konsep yang mengintegrasikan nilainilai syari'ah ke dalam kegiatan pariwisata dengan menyediakan fasilitas dan pelayanan yang sesuai dengan ketentuan syariah. Hal ini memiliki arti bahwa perlindungan hukum terhadap wisatawan muslim yang memiliki kewajiban berdasarkan tuntunan agama juga memiliki kebutuhan ibadah dengan tetap melakukan kegiatan pariwisata. Sehingga Perda NTB No. 2 Tahun 2016, disamping mengedepankan aspek kemanfaatan ekonomi, juga memberikan keamanan dan kenyamanan pelayanan kepada wisatawan agar dapat menikmati kunjungan wisata dengan aman, halal dan juga dapat memperoleh kemudahan bagi wisatawan dan pengelola dalam kegiatan kepariwisataan. Berdasarkan ketentuan dalam Perda No. 2 Tahun 2016, maka pariwisata halal dikelompokan kedalam 2 (dua) jenis, yaitu destinasi dan industri pariwisata.

Secara umum, setelah proses formulasi dilakukan oleh legislatif dan eksekutif maka dilakukan proses komunikasi atau penyebaran informasi oleh dinas terkait. Salah satunya yang cukup intensif adalah Dinas Pariwisata provinsi NTB. Pemprov NTB juga sudah bekerja sama dengan MUI membuka pusat informasi wisata halal yang ditempatkan satu lokasi dengan kantor MUI. Selain itu, targetnya adalah pelaku usaha wisata, baik usaha perhotelan, restaurant, spa, dan akomodasi. Selain itu masyarakat wisata juga diberikan informasi terkait ketersedian lokasi yang sudah mengimplementasikan konsep wisata halal ini. Untuk lebih detail bisa melihat alur dibawah ini:

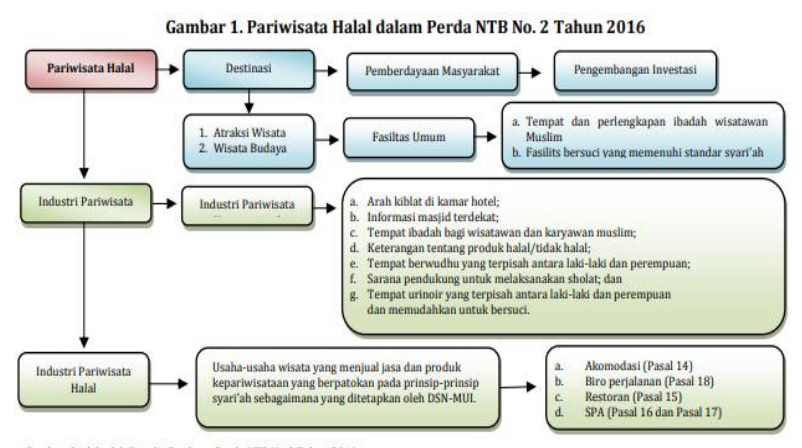

\section{b) Sumber Daya}

Sumber daya disini bisa terdiri dari beberapa jenis, seperti sumber daya anggaran dan SDM:

\section{Sumber Daya Anggaran:}

Sebagai wujud kesungguhan Kementerian Pariwisata Negara Indonesia untuk mendukung upaya peningkatan angka kunjungan wisatawan ke provinsi NTB, pada 2016 anggaran promosi pariwisata untuk NTB lebih banyak lagi. Alokasi anggaran untuk promosi pariwisata akan ditingkatkan menjadi tiga kali lipat. Kementerian Pariwisata dan Dinas Pariwisata NTB juga telah melakukan promosi di berbagai negara di kawasan Timur Tengah. Dari 32 pasal di dalam perda wisata halal. Yakni pasal 31 yang menyebutkan bahwa pemerintah wajib menyediakan pembiayaan melalui APBD dalam pengembangan pariwisata.

Sebagai wujud keseriusan mengembangkan konsep wisata syariah di NTB, pemerintah membangun sebuah destinasi wisata berkelas dunia di Kawasan Ekonomi Khusus (KEK) Mandalika di Kabupaten Lombok Tengah. Investasi infrastruktur dasar tahap pertama diperkirakan sebesar Rp250 miliar direncanakan akan berasal dari Penyertaan Modal Negara $(\mathrm{PMN})$, sisanya akan diupayakan sendiri oleh ITDC dari pinjaman lunak berbagai institusi keuangan dalam dan luar negeri. Menurut narasumber, "Kami optimitis dengan dukungan dari berbagai pihak, khususnya pemerintah pusat dan Pemprov NTB, pengembanganan KEK Pariwisata Mandalika akan berjalan sesuai rencana dan memberikan kontribusi positif terhadap perekonomian masyarakat NTB pada khususnya dan juga pendorong perekonomian nasional,".

\section{Sumber Daya Manusia dan Keterlibatan Pihak lain}

Hampir semua pihak ingin terlibat dalam proses menciptakan konsep wisata halal atau islami. Tidak hanya dinas Pariwisata NTB, tetap juga berbagai pihak. Hal ini dibuktikan dengan adanya keterlibatan berbagai pihak seperti Asosiasi Pariwisata Islami Indonesia (APII). APII secara resmi merilis pembentukan 99 desa wisata halal di NTB. Hal ini bertujuan untuk mempertegas NTB khususnya Lombok sebagai destinasi wisata halal terbaik di Indonesia bahkan dunia. Menurut Ketua APII TGH Fauzan Zakaria, terbentuknya 99 desa wisata halal merupakan inisiasi masyarakat, dengan kesadarannya melihat potensi yang ada, mereka bergerak mengelola dan membangun desa 
menuju kesejahteraan. Ia berujar, launching 99 desa wisata ini merupakan salah satu bentuk gerakan masyarakat bersama para pengusaha di bidang pariwisata yang berhimpun di bawah APII. Lebih lanjut, "Pembangunan yang baik adalah yang diinisiasi dan dimotori oleh masyarakat lalu difasilitasi oleh pemerintah. 99 Desa wisata halal se-NTB yang berkumpul dalam APII sebagai salah satu langkah kongkrit mewujudkan Lombok-Sumbawa sebagai destinasi halal terbaik,".

\section{c) Struktur Birokrasi (Tim khusus dalam \\ Pelaksanaan Perda)}

Menurut narasumber H.M. Haris selaku Kepala Seksi Pariwisata Halal Bagian Pemasaran menyampaikan bahwa banyak pihak atau tim melaksanakan perda ini. Semua ingin ikut berpartisipasi mendukung konsep yang sudah disepakati ini. Lebih detail "Proses sertifikasi halal untuk Disbudpar berkoordinasi dengan Disperindag, Dinas Kesehatan dan diluar itu bersama MUI NTB. Kami juga intens melakukan seminar dan sosialisasi bersamasama. Untuk tahun 2016 dan 2017 fokus pariwisata halal memang sebagian besar perencanaan dan tahapan awal pembangunan, jadi belum terdapat pariwisata halal yang benarbenar murni, masih kalah dengan wisata konvensional biasa, tetapi upaya kami memperhatikan kebutuhan wisatawan muslim dengan memberikan petunjuk dan informasi yang detail". Lebih lanjut menurut narasumber "Pemerintah daerah NTB sedang mengembangkan wisata pantai khusus dengan konsep halal beach. Di beberapa pantai akan ada dan di usahakan wisatawan laki-laki dan perempuan untuk dipisah. Halal beach kita sekarang sedang tahapan pengerjaan, tahun ini sudah kita mulai pembangunan awalnya, ada dua kawasan pantai di pulau Lombok yang akan dikembangkan menjadi konsep pantai halal, di antaranya di kawasan Meninting, Lombok Barat dan kawasan Mandalika, Lombok Tengah. Di lokasi pantai halal ini nantinya akan ada pembatas permanen yang memisahkan antara wisatawan laki-laki dan wisatawan perempuan. Makanan yang disediakan di lokasi tersebut adalah makanan yang halal".

Dalam penghargaan World's Best Halal di Dubai tahun 2015, Lombok selama bertahuntahun sudah lebih dahulu dikenal karena memiliki banyak sekali pantai yang indah dan eksotis. Dengan adanya penghargaan pariwisata halal terhadap Lombok maka promosi wisata tahun 2016 khususnya lebih digencarkan, peran Badan Promosi Pariwisata Daerah BPPD-NTB sesuai dengan arahan Pemerintah Daerah, kerjasama juga dilakukan dengan Asita-NTB, guna melakukan promosi kepada dunia internasional. Kesuksesan konsep Pariwisata halal ini mendapatkan perhatian yang lebih terutama setelah disahkannya Perda Pariwisata halal NTB, Dinas Pariwisata juga dilibatkann dalam proses penyusunan, sehingga amanat Perda selalu menjadi prioritas kami di tahun 2017 dalam melakukan promosi pariwisata halal, walaupun pariwisata halal masih banyak kendala pada standarisasinya dalam pelaksanaanya, sebenarnya promosi dan pengembangan destinasi harus berimbang.

\section{d) Faktor Disposisi}

Sikap pegawai/anggota Dinas Pariwisata terhadap dikeluarkannya Perda no 2 tahun 2016 tentang Pariwisata halal ini disampaikan narasumber, Bapak H. M. Haris dalam wawancara menyatakan bahwa "adanya perda ini membawa dampak positif terhadap pariwisata halal karena hadirnya perda nomor 2 tahun 2016 dapat meningkatkan wisatawan dan faktor hukum merupakan faktor penting yang berfungsi sebagai pendorong penyelenggaraan dan peningkatan pariwisata halal di NTB. Oleh karena itu nantinya akan semakin banyak aktivitas yang mereka lakukan guna mencapai tujuan tersebut". Dalam pandangan Kelsen, hukum mempunyai karakter imperatif. Artinya ada kewajiban untuk melaksanakan hokum, dalam hal ini adalah Perda.

Disisi lain, dapat kita simpulkan dari hasil penelitian ini bahwa lahirnya Pergub NTB No.1 Tahun 2015 kemudian Perda NTB No. 2 Tahun 2016 menandai optimalisasi peran pemerintah daerah dalam meningkatkan pelayanan pariwisata halal. Perda NTB No. 2 Tahun 2016 merupakan peraturan perundang-undangan yang mengatur khusus pariwisata halal dan secara tegas menentukan ketentuan-ketentuan dalam penyelenggaraan pariwisata halal yang menentukan standar umum yang harus dipenuhi oleh destinasi dan industri baik yang konvensional maupun khusus pariwisata halal.

b. Faktor Penghambat yang mempengaruhi proses Implementasi Kebijakan Pariwisata Halal di NTB berdasarkan Peraturan Daerah Provinsi NTB No.2 tahun 2016 Tentang 
Pariwsata Halal oleh Dinas Pariwisata Provinsi NTB.

a) Masing Kurangnya Objek Wisata Halal

Provinsi Nusa Tenggara Barat (NTB) selain dikenal memiliki panorama alamnya yang indah, Pulau Lombok, satu diantara dua pulau besar di NTB juga populer dengan sebutan "Pulau Seribu Masjid". Julukan itu rasanya tak berlebihan kalau melihat fakta yang ada. Menurut penelitian Taufan Hidjaz, yang kemudian dibukukan dengan judul "Lombok, Negeri Beribu Mesjid", dari 518 desa yang ada di Pulau Lombok, terdapat sekitar 9000-an masjid. Harusnya terdapat banyak masjid yang bisa dijadikan objek wisata religi yang mendukung konsep pariwisata halal. Pada saat sekarang, yang mungkin sudah popular seperti Islamic Center, Masjid Kuno Bayan dan di pulau Sumbawa ada masjid peninggalan kesultanan Bima.

\section{Islamic Center:}

Satu diantara masjid-masjid yang ada di Lombok, terindah, terbesar dan termegah, dengan menaranya yang menjulang tinggi ke angkasa hingga 114 meter, adalah Masjid Hubbul Wathan di kompleks Islamic Center NTB, yang selama sebulan ini menjadi lokasi pelaksanaan even Pesona Khazanah Ramadhan (PKR) 2018. Masjid yang sudah digagas dan dirancang sejak zaman Gubernur H. Warsito, H. Harun Al Rasyid, dan H. Lalu Serinata dan akhirnya dibawah kepemimpinan Tuan Guru Bajang (TGB) Dr. HM Zainul Majdi berhasil diwujudkan oleh Pemerintah Provinsi NTB. Menurut keterangan pers TGB: "Disamping sebagai tempat ibadah, Islamic Center NTB juga telah ditetapkan sebagai destinasi wisata religi oleh Pemerintah Daerah".

\section{Masjid Bayan:}

Pulau Lombok, di provinsi Nusa Tenggara Barat, terkenal dengan keindahan Gunung Rinjani dan Pantai Senggigi-nya yang menawan. Pulau nan indah disebelah timur pulau Bali ini menyimpan bukti sejarah perkembangan Islam yang teramat tua namun masih terawat dengan baik hingga kini. Sebuah Masjid berarsitektur tradisional khas Pulau Lombok bernama Masjid Bayan Beleq. Masjid Bayan Beleq kini menjadi salah satu ikon pariwisata kabupaten Lombok
Utara, bersama sama dengan Gunung Rinjani. Masjid kuno ini juga diabadikan dalam lambang daerah kabupaten Lombok Utara. Masjid Kuno Bayan Beleq di gambar dalam bentuk siluet bewarna merah menggambarkan integritas peradaban masyarakat Lombok Utara.

\section{Masjid Kesultanan Bima.}

Masjid yang terletak di kampung Sigi atau di sebelah selatan lapangan Sera Suba ini adalah bukti sejarah keemasan kesultanan Bima. Masjid ini dibangun oleh Sultan Abdul Kadim Muhammad Syah dengan Wajir Ismail pada tahun 1737. Pembangunan selanjutnya dilakukan oleh Sultan Abdul Hamid dengan merubah atap masjid tersbut menjadi bersusun tiga yang mirip dengan masjid Kudus.

\section{b) Masing Kurangnya Kesadaran Pelaku Usaha untuk Mewujudkan Konsep Pariwisata Halal}

Beberapa bidang yang sudah ditentukan bisa menerapkan konsep wisata halal masih menerapkan konsep wisata konvensional. Hal ini terkait belum adanya kesamaan persepsi antar pelaku usaha. Seharusnya para pelaku usaha pariwisata konvensional ikut mendorong menciptakan suasana pariwisata dengan nuansa islami ini.

\section{Simpulan}

Berdasarkan pembahasan hasil penelitian diatas, maka dapat disimpulkan yaitu:

1. Proses Implementasi Kebijakan Pariwisata Halal di NTB berdasarkan Peraturan Daerah Provinsi NTB No.2 tahun 2016 Tentang Pariwisata Halal oleh Dinas Pariwisata Provinsi NTB sudah berjalan dengan baik namun belum maksimal. Faktor komunikasi, sumberdaya, disposisi dan struktur birokrasi sudah dijalankan untuk mensukseskan kebijakan ini.

2. Faktor penghambat dalam mempengaruhi proses Implementasi Kebijakan Pariwisata Halal di NTB berdasarkan Peraturan Daerah Provinsi NTB No.2 Tentang Pariwisata Halal oleh Dinas Pariwisata Provinsi NTB yaitu masing kurangnya objek wisata halal dan masing kurangnya kesadaran pelaku usaha untuk mewujudkan konsep pariwisata halal.

\section{Saran}

1. Menambah objek, ikon atau daerah dengan konsep pariwisata halal seperti desa wisata 
islami dan membuka penerbangan langsung Lombok-Timur Tengah.

2. Memberikan training kepada pelaku usaha untuk dapat membantu atau menciptakan suasana yang mendukung konsep pariwisata halal.

\section{DAFTAR RUJUKAN}

[1] Abdul Wahab, Solichin, Analisis Kebijakan dari Formulasi ke Penyusunan Model-model Implementasi Kebijakan Publik, Bumi Aksara, Jakarta, 2012.

[2] Agustino, Leo, Dasar-dasar Kebijakan Publik., CV. Alfabeta, Bandung, 2008.

[3] Battour, Mohamed and Ismail, Nazari, Halal Tourism: Concepts, Practises, Challenges and Future. Tourism Management Perspective Journal, http://dx.doi.org/10.1016/j.tmp.2015.12.008, pp. 1-5. 2015.

[4] Duman, Teoman, Value of Islam Tourism offering: Perspective from The Turkish Experience. Paper Presented in World Islamic Tourism Forum (WITF), Kuala Lumpur: Malaysia. 2011.

[5] Dye, Thomas, Understanding Public Policy, Prentice Hall, Inc, New Jersey, 1978.

[6] Firmansyah et al., Kesiapan Lombok Sebagai Pusat Destinasi Wisata Halal Dunia dan Faktor Penentu Yang Perlu Disiapkan Dalam Pengembangan Wisata Halal .Laporan Kerja DRD Provinsi NTB. 2016.

[7] Isfahani, Ali Nejatbakhsh et al, To Investigate Influential Factors on Halal Brand in the Global Markets.Journal of Basic and Applied Scientific Research, 3 (1) pp.958-963, Iran. 2013.

[8] Jaelani, Aan, Halal Tourism Industry in Indonesia: Potential and Prospects. MPRA Paper No. 76235 posted 16-01-2017, https://mpra.ub.uni-muenchen.de/76235// 2017.

[9] Master Card \& Crescen Rating, Global Muslim Travel Index 2016. 2016.

[10] Moleong, Lexy J, Metode Pelelitian Kualitatif, PT. Remaja Rosdakarya, Bandung, 2017.

[11] Medhekar, Anita and Haq, Farooq, Halal Branding for Medical Tourism: Case of Indian Hospital, 2015.

[12] Nugroho, Riant, Public Policy, PT Elex Media Komputindo, Jakarta, 2011.

[13] Peraturan Daerah Provinsi Nusa Tenggara Barat Nomor 2 Tahun 2016 tentang Pariwisata Halal
[14] United Nations, World Tourism Organization, Recommendations on Tourism Statistics. Series M, No 83, New York. 1994.

[15]Winarno, Budi, Kebijakan Publik (Teori, Proses dan Studi Kasus), CAPS, Jogjakarta, 2012.

[16]Zamani Farahani, H \& Henderson, J.C., Islamic Tourism and Managing Tourism Development in Islamic Societies: The Case of Iran and Saudi Arabia. International Journal of Tourism Research, 12, pp. 79-89. 2010. 